\title{
PENYISIHAN COD LIMBAH CAIR INDUSTRI BATIK DENGAN METODE FITOREMEDIASI PADA SSF-WETLAND MENGGUNAKAN TANAMAN OBOR (Typha Latifolia) dan TANAMAN TASBIH (Canna Indica.L)
}

\author{
Ernastin Maria \\ Program studi Teknik Industri \\ Fakultas Teknologik Industri, Institut Teknologi Yogyakarta (STTL- \\ "YLH") \\ E-mail: ernastinmaria@ity.ac.id* \\ Telpon: 081215566483*
}

\begin{abstract}
ABSTRAK
Industri batik merupakan salah satu pendukung pertumbuhan ekonomi di Desa Wijirejo, Kabupaten Pandak, Bantul. Kandungan limbah batik dengan zat organik seperti BOD dan COD yang tinggi mnjadi penyebab pencemaran lingkungan. Umumnya para pengrajin industri batik Desa Wijirejo membuang limbah produksi batik secara langsung ke saluran air (selokan) menuju aliran sungai Bedog tanpa pengolahan terlebih dahul yang dapat menyebabkan penurunan kualitas air. Penelitian ini bertujuan untuk mengetahui efisiensi tanaman air Typha latifola dan Canna Indica $L$. dalam menurunkan kadar pencemar air limbah industri batik COD pada SSF-Wetland dengan media pasir dan kerikil selama 8 hari. Air limbah yang digunakan adalah efluen dari salah satu industri batik di Desa Wijirejodengan konsentrasi awal COD sebesar 4800,215 mg/L.

Berdasarkan proses fitoremediasi pada SSF-Wetland hasil penelitian menunjukan bahwa konsentrasi COD dalam air limbah pada SSF-wetland menurun seiring bertambahnya waktu tinggal hidraulik (hydraulic retention time). Selama delapan hari penelitian, efisiensi penyisihan COD terbesar pada tanaman Typha dan tanaman Canna yakni pada hari ke-8 penelitian dengan penurunan konsentrasi cOD tanaman Typha sebesar 429,6 mg/L menunjukan persentase penyisihan sebesar 91 $\%$, dan pada tanaman Canna penurunan konsentrasi COD 410,77 mg/L dengan persentase penyisihan $91,4 \%$. Dengan demikian hasil penelitian menunjukan bahwa tanaman Typha Latifolia dan tanaman Canna Indica L. mempunyai kemampuan yang sama dalam penyisihan limbah cair industri batik yakni COD.

Kata Kunci: SSF-Wetland, Limbah Cair Batik, Fotoremidiasi, Canna Indica.L. Typha Latifolia
\end{abstract}




\title{
SEPARATION OF WASTE COD FROM BATIK INDUSTRIAL LIQUID WITH FITOREMEDIATION IN SSF-WETLAND USING DRILLING PLANTS (Typha Latifolia) and TASBIH PLANTS (Canna Indica L.)
}

\begin{abstract}
The batik industry is one of the supporters of economic growth in Wijirejo Village, Pandak Regency, Bantul. The content of batik waste with organic substances such as $B O D$ and $C O D$ is a high cause of environmental pollution. Generally, the batik industry craftsmen in Wijirejo Village dispose of batik production waste directly into waterways (sewers) to the Bedog river flow without prior treatment which can cause a decrease in water quality. This study aims to determine the efficiency of Typha latifola and Canna Indica L. aquatic plants in reducing pollutant levels of COD batik industrial wastewater in SSF-Wetland with sand and gravel for 8 days. The wastewater used is an effluent from one of the batik industries in Wijirej village with an initial concentration of COD of $4800.215 \mathrm{mg} / \mathrm{L}$.

Based on the SSF-Wetland phytoremediation process, the results showed that the COD concentration in wastewater in SSF-wetland decreased with increasing hydraulic retention time. During the eight days of research, the highest COD removal efficiency in Typha and Canna plants ie on the 8th day of the study with a decrease in Typha plant COD concentrations by $429.6 \mathrm{mg} / \mathrm{L}$ showed that the percentage of removal was $91 \%$ and COD 410 decreased, $77 \mathrm{mg} / \mathrm{L}$ with the percentage of allowance $91.4 \%$. Thus the results of the study show that Typha Latifolia and Canna Indica L. plants have the same ability in the removal of liquid waste in the batik industry, namely COD.
\end{abstract}

Keywords: SSF-Wetland, Batik Liquid Waste, Photoremidiation, Canna Indica.L. Typha Latifolia 


\section{A. PENDAHULUAN}

Desa Wijirejo merupakan salah satu sentra industri batik yang terkenal dengan batik tulis dan batik capnya. Desa ini terdiri dari beberapa home industry yang tergabung menjadi sebuah kelompok pengrajin batik. Hal tersebut menjadikan desa ini menjadi cukup potensial dalam menyumbang pertumbuhan perekonomian lokal namun permasalahannya belum terdapat pengolahan air limbah dalam proses produksinya dimana kegiatan produksi batik tidak pernah lepas dari resiko negatif yang berakibat terjadinya perubahan lingkungan karena pencemaran yang ditimbulkan.

Limbah yang dihasilkan dari industri batik adalah limbah cair yang mengandung kadar BOD, COD, TSS, zat warna, lemak dan minyak. Karena polutan yang terkandung dalam limbah cair industri batik umumnya mengandung padatan tersuspensi, zat organik dan logam berat, jika dibuang secara langsung ke lingkungan tanpa pengolahan terlebih dahulu maka akan berpotensi menimbulkan pencemaran pada sungai, dapat menurunkan kualitas air dan mempengaruhi ekosistem setempat. Dari aspek penggunaan bahan kimia, industri batik merupakan industri yang potensial menghasilkan limbah yang mengandung logam berat yang dikategorikan sebagai limbah berbahaya sehingga dapat menyebabkan pencemaran lingkungan (Ninggar, 2014). Umumnya para pengrajin industri batik Desa Wijirejo membuang limbah produksi batik secara langsung ke saluran air (selokan) menuju aliran sungai Bedog tanpa pengolahan terlebih dahulu. Hal ini mempengaruhi kualitas air sungai Bedog karena pembuangan limbah cair batik dilakukan secara terus menerus setiap hari akan berakibat menurunkan kualitas air dan mempengaruhi ekosistem persiran sungai Bedog sehingga dapat membahayakan biota yang terdapat dalam perairan dan membahayakan kesehatan manusia bila mngkonsumsi air maupun biota tersebut. Oleh karena itu diperlukan suatu metode untuk dapat menanggulangi permasalahan yang ditimbulkan dari limbah cair industri batik.

Salah satu metode pengolahan limbah murah, mudah dan aplikatif yang dapat dilakukan adalah Sistem Lahan Basah Aliran Bawah Permukaan (Sub Surface Flow-Wetlands) merupakan salah satu sistem pengolahan air limbah yang prinsip kerjanya memanfaatkan simbiosis antara tumbuhan air dengan mikroorganisme dalam media disekitar sistem perakaran tanaman. Wetland merupakan suatu lahan yang jenuh air dengan kedalaman air 
tipikal yang kurang dari 0,6 m yang mendukung pertumbuhan tanaman air emergent seperti Cattail, Bulrush, Umbrelle plant, dan lainlain, memiliki efisiensi penghilangan suspensi padat pada kolom air yang cukup besar yakni berbagai macam kontaminan, seperti nutrien, logam berat, atau ikatan fisika atau kimia. Murahnya biaya konstruksi maupun biaya

\section{B. TINJAUAN PUSTAKA}

Parameter utama air limbah yang terkandung dalam industri tekstil berdasarkan Peraturan Daerah Provinsi Jawa Tengah No 10 Tahun 2004 meliputi: Warna, Temperatur, Debit maksimum, BOD, COD, TSS, $\mathrm{pH}$, Fenol, $\mathrm{Cr}, \mathrm{NH}_{3} \mathrm{~N}, \mathrm{~S}$, minyak dan lemak. COD ( Chemical Oxygen Demand) dalam air limbah menunjukan besarnya kebutuhan oksigen total yang dibutuhkan untuk mengoksidasi zat-zat organik yang terdapat dalam air limbah secara kimia. Penyebab utama peningkatan COD adalah bahan-bahan aktof sintesis (Artificial Active Agents) dan bahan perekat campuran yang digunakan industri batik. COD maksimum yang diperbolehkan pada limbah batik yaitu sebesar $150 \mathrm{mg} / \mathrm{L}$. Semakin tinggi COD maka akan semakin tinggi pula pencemaran yang dihasilkan.

Sistem aliran bawah permukaan (Sub surface constructed wetland) adalah saluran yang diisi pasir dan kerikil, yang ditanami operasional dapat mendukung keberhasilan pengolahan air limbah secara berkelanjutan. Penelitian ini dimaksudkan untuk mengetahui kemampuan tanaman obor (Typha Latifolia) dan tanaman Tasbih (Canna Indica.L) dalam menurunkan kandungan COD pada SSF-Wetland limbah cair industri batik

vegetasi air. Air limbah mengalir horizontal melalui saluran berisi material penyaring yang berfungsi menguraikan zat organic. Sistem ini merupakan sistem pengolahan limbah yang mulai banyak diteliti dan dikembangkan oleh banyak negara. (Anonim dalam Subiyantoro, 2015).

Mekanisme penyerapan polutan pada lahan basah buatan menurut USDA dan ITRC dalam Halverson (2004) menyebutkan bahwa secara umum melalui proses abiotik (Fisik dan kimia) atau biotik (mikrobia dan tanaman) dan gabungan dari kedua proses tersebut.

\section{METODE PENELITIAN}

Penelitian ini menggunakan variabel bebas terdiri dari 2 jenis tanaman yaitu Typha latifolia (Tanaman Obor) dan Canna Indica L .(Tanaman Tasbih) dengan lama tinggal $0,1,2,3,4,5,6,7$ dan 8 hari. Sedangkan variabel terikat adalah kadar COD dan $\mathrm{pH}$ pada hari ke-0, 1 , 2, 3, 4, 5, 6, 7 dan 8. Bahan dan peralatan dalam penelitian ini adalah 
sebagai berikut: Bak plastik dengan ukuran $60 \mathrm{~cm}$ x $40 \mathrm{~cm}$, media (kerikil diameter 5-30 mm, pasir), tanaman (Typha latifolia dan Canna Indica L.), efluen air limbah industri batik dan bahan/aksesoris lainnya (Gambar 2).
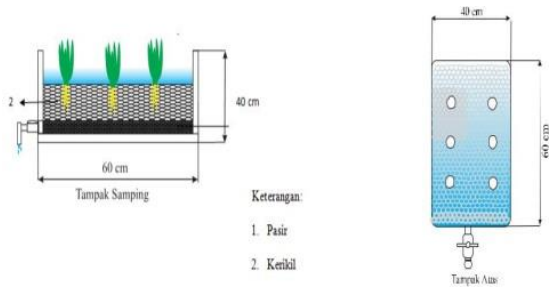

Gambar 1. Rancangan alat penelitian SSF- wetland

Penelitian ini terdiri dari 3 bak (unit wetland artifisial SSF) yakni bak A (tanaman Typha) menggunakan media pasir setebal 8 $\mathrm{cm}$ dan kerikil setebal $22 \mathrm{~cm}$, bak B (Canna) menggunakan media pasir dengan ketebalan $8 \mathrm{~cm}$ dan kerikil setebal $22 \mathrm{~cm}$ dan bak $\mathrm{C}$ merupakan bak kontrol tanpa tanaman menggunkan media kerikil. Tanaman yang digunakan telah didiamkan selama 7 hari untuk penyesuaian kondisi pada tempat penelitian (suhu, sinar matahari). Air limbah untuk sistem SSF-wetland artifisial pada penelitian ini diambil dari salah satu home industri batik melalui outlet dengan cara ditampung terlebih dahulu dengan ember, untuk kemudian dituang dengan cara genangan (batch) dengan volume 20 liter untuk setiap bak. Setelah semua bak siap dan sesuai dengan sistem yang direncanakan, dilakukan aklimatisasi. Untuk masa aklimatisasi, tanaman ditanam pada unit SSF-wetland dengan kerapatan $\pm 200 \mathrm{gr} / \mathrm{cm}^{2}$, lalu diaklimatisasi selama 15 hari dengan rincian yaitu pada tahap awal semua bak digenangi dengan konsentrasi $100 \%$ air bersih selama 3 hari kemudian dikosongkan dan diganti dengan campuran $25 \%$ air limbah $( \pm 5 \mathrm{~L})$ dan $75 \%$ air bersih ( \pm 15 L) selama 3 hari kemudian dikosongkan kembali fan diganti dengan 50\% air limbah $( \pm 10 \mathrm{~L})$ dan $50 \%$ air bersih $( \pm 10 \mathrm{~L})$ selama 3 hari kemudian dikosongkan lagi dan diganti dengan 25\% air bersih $( \pm 5 \mathrm{~L})$ dan $75 \%$ air limbah $( \pm 15 \mathrm{~L})$ selama 3 hari selanjutnya dikosongkan lagi untuk kemudian digenangi kembali dengan konsentrasi $100 \%$ air limbah $( \pm$ 20L). Tahap awal penelitian dilakukan dengan mengambil sampel limbah cair industri batik pada kondisi konsentrasi $100 \%$ air limbah dan diuji laboratorium untuk mengetahui kadar polutan sebagai kondisi awal (hari ke-0). Penelitian selanjutnya dilakukan dengan mengambil sampel dimasing-masing bak wetland artifisial $\mathrm{A}, \mathrm{B}$, yang berisi tanaman dan bak $\mathrm{C}$ untuk bak kontrol, pada hari ke 1, 2, 3, 4, 5, 6, 7 dan 8 untuk kemudian di bawa ke laboratorium untuk di uji kadar polutannya COD dan $\mathrm{pH}$.

D. HASIL DAN PEMBAHASAN

3.1. Kondisi Fisik Tanaman 
Secara signifikan limbah tidak mempengaruhi kenampakan morfologi pertumbuhan tanaman. Mulai hari ke-0 tanaman dapat tumbuh dengan baik hal ini ditunjukan dengan daun tanaman yang tampak berwarna hijau, segar dan tidak layu. Anakan tanaman Typha yang tumbuh saat proses aklimatisasi terus bertumbuh hingga hari ke-8 penelitian anakan tanaman hampir sama dengan induknya. Pada tanaman Canna pertumbuhannya juga sangat baik, anakan tanaman yang tampak terlihat pada hari ke-2 terus bertumbuh dan bertambah besar sampai hari terakhir penelitian. Kondisi tersebut memunjukan bahwa baik tanaman Typha maupun tanaman Canna dapat beradaptasi .

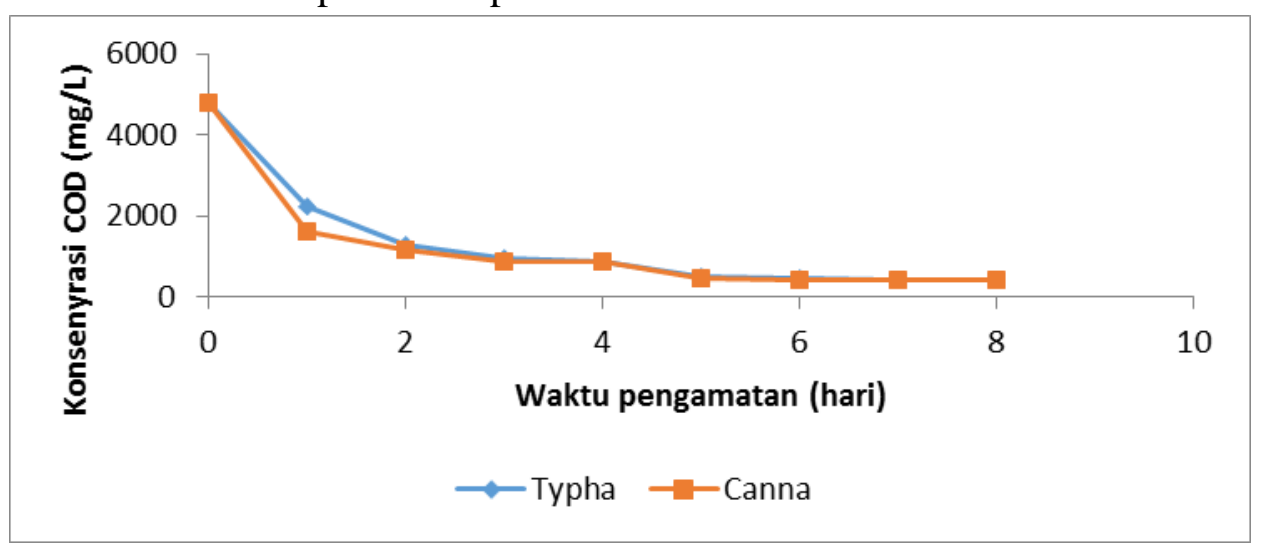

Gambar 2. Fluktuasi COD Tanaman Typha Latifolia dan Canna Indica L

Berdasarkan grafik (gambar 2) terlihat bahwa konsentrasi COD pada SSF-Wetland untuk kedua tanaman yakni tanaman Typha dan tanaman Canna cenderung mengalami penurunan, menurun tajam diawal
3.2. Fluktuasi COD pada SSFWetland dengan Tanaman Typha Latifolia dan Tanaman Canna Indica $L$.

Konsentrasi parameter COD pada unit Wetland artifisial sistem SSF dengan menggunakan tanamanTypha dan tanaman Canna dapat disajikan dalam bentuk grafik (Gambar 2 ) sebagai berikut: 
Canna, hal ini dikarenakan fase pertumbuhan mikroorganisme masuk pada fase exponensial growth phase yang ditandai dengan terjadinya percepatan pertumbuhan bakteri sehingga bahan organik (COD) yang terdegradasi juga mengalami percepatan. Pada hari berikutnya efisiensi penyisihan terus meningkat, hal ini dapat dilihat dengan penurunan konsentrasi COD yang terjadi pada ke-2 tanaman tersebut bahkan pada hari terakhir penelitian konsentrasi COD turun menjadi 429,6 $\mathrm{mg} / \mathrm{L}$ (efisiensi penurunan 91,1\%) untuk tanaman Typha, dan turun menjadi 410,77 $\mathrm{mg} / \mathrm{L}$ (efisiensi penurunan 91,4\%) untuk tanaman Canna. Dapat dikatakan bahwa performa dari sistem SSF-Wetland baik menggunakan tanman Typha maupun tanman Canna cukup stabil. Hal ini menunjukan bahwa bakteri sudah dapat beradaptasi dan berkembangbiak dengan baik, populasi bakteri yang bertambah mempercepat proses dekomposisi nutrien yangnantinya diserap oleh tanaman. begitu pula jika dilihat pada kondisi fisik tanaman yang terus tumbuh semakin subur sehingga proses pendegradasian bahan organik berjalan baik.

Menurut Metchaf \& Eddy dalam Supradata (2005) karakteristik pertumbuhan bakteri dalam reaktor sistem batch berdasarkan waktu ada 4 fase pertumbuhan. Sehingga peran utama mikroorganisme dalam mendegradasi bahan organik dam sistem wetland akan menjelaskan trend penurunan bahan organik dari hasil percobaan. Proses aklimatisasi tamnaman pada awal percobaan telah memberi kesempatan pada bakteri yang terdapat di rhizosfer untuk tumbuh dan beradaptasi, sehingga lagh-phase terjadi pada proses ini, sehingga pada awal penelitian pertumbuhan bakteri telah mencapai fase pertumbuhan eksponensial (Exponensial Growth Phase). Kondisi inilah yang menjelaskan bahwa penurunan BOD dan COD pada tanaman Typha dan tanaman Canna pada awal penelitian mengalami penurunan yang tajam.

\subsection{Konsentrasi pH pada SSF- Wetland dengan Tanaman Typha Latifolia dan Tanaman Canna Indica $L$.}

Derajat keasaman atau $\mathrm{pH}$ merupakan salah satu parameter yang digunakan dalam penelitian ini. Peranan pH sangat penting karena mikroorganisme memerlukan lingkungan dengan $\mathrm{pH}$ terterntu. Secara umum nilai $\mathrm{pH}$ yang ditolerir dalam mikroorganisme adalah pada kisaran 6,5-8,5 pH yang tidak sesuai akan akan dapat menurunkan kinerja proses biologi karena mikroorganisme tidak dapat melakukan metabolisme secara optimal (Khaitudin dalam Subiyantoro, 2015)

Sampai akhir penelitian $\mathrm{pH}$ cenderung stabil yakni berkisar antara $6-7$ serta pertumbuhan kondisi ke dua tanaman cukup baik. 
Hal ini menunjukan bahwa kadar keasaman air limbah pada ke dua bak reaktor hampir sama dan masih termasuk dalam rentang $\mathrm{pH}$ yang dapat ditolerir oleh mikroorganisme.

Berikut adalah grafik yang menunjukan nilai $\mathrm{pH}$ unit SSFWetland pada ke dua tanaman:

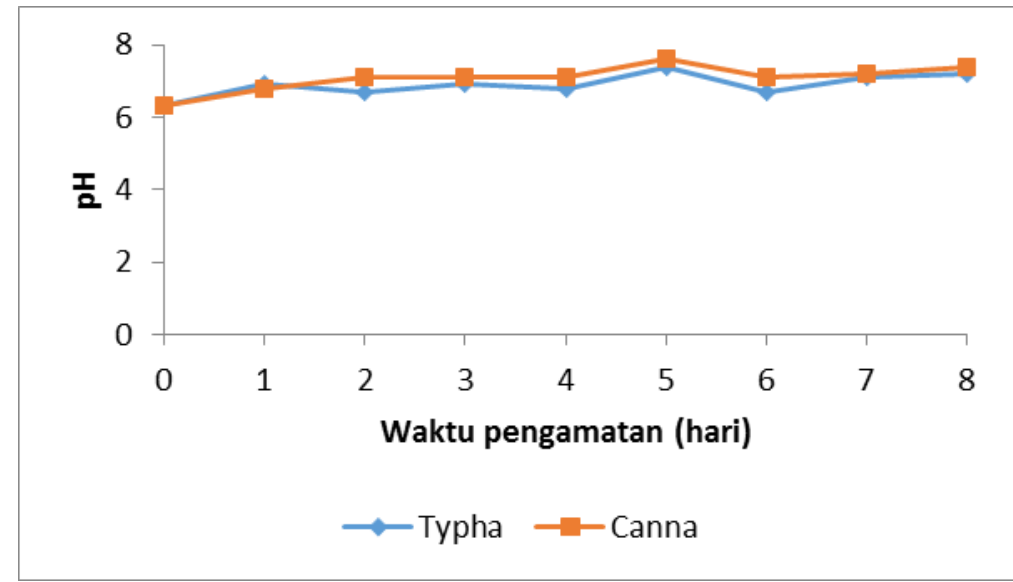

Gambar 3. pH pada unit SSF-Wetland dengan tanaman Typha Latifolia dan Tanaman Canna Indica L.

\section{SIMPULAN}

Fitoremediasi pada SSFWetland merupakan metode alternatif yang cocok dalam meremoval limbah cair industri batik karena sistem ini dapat menurunkan konsentrasi polutan dalam air limbah seiring bertambahnya waktu tinggal hidraulik (hydraulic retention time). Hasil pengujian menunjukan bahwa selama 8 hari penelitian, SSFWetland menggunakan tanaman Obor (Typha Latifolia) dan tanaman Tasbih (Canna Indica L.) mampu menurunkan konsentrasi polutan yakni Konsentrasi COD tanaman Typha turun menjadi 429,6 mg/L (efisiensi penurunan $91 \%$ ) dan tanaman Canna turun menjadi 410,77 $\mathrm{mg} / \mathrm{L}$ (efisiensi penurunan 91,4\%)

\section{SARAN}

Fitoremediasi dengan sistem wetland artifisial SSF sebaiknya dapat digunakan sebagai pengolahan limbah cair industri batik baik pada skala rumah tangga maupun pada industri yang lebih besar.

Perlu penelitian lebih lanjut mengenai laju penyerapan COD pada unit wetland artifisial SSF dengan tanaman Typha dan Cyperus dengan mempertimbangkan berbagai faktor seperti media, degradasi oleh mikroorganisme, evapotranspirasi pada tanaman dan faktor-faktor lainnya, sehingga diperoleh dan dikembangkan laju dan pemodelan matematis penurunan polutan pada sistem ini. 


\section{DAFTAR PUSTAKA}

Halverson, 2004, Review of Constructed Wetlands

Flow Vs. Surface Flow Wtlands, U.S. Departement Of Energy, Springfieel, USA.

Ninggar, R.D. 2014, Kajian Yuridis

Tentang Pengendalian Limbah Batik Di Kota Yogyakarta, Yogyakarta; Naskah Skrpsi-S1, Fakultas hukum Universitas Gadjah Mada.

Subiyantoro. E, 2015, Penurunan Nutrien dan BOD-COD dari Efluen IPAL Komunal dengan Fitoremediasi pada Wetland Artifisial, Yogyakarta: Tesis UGM.

Supradata, 2005, Pengolahan Limbah Domestik Menggunakan Tanaman Hias Cyperus Alternifolius, L. Dalam Sistem Lahan Basah Buatan Aliran Bawah Permukaan (SSF Wetlands), Semaranag: Tesis UNDIP. 